\title{
A Mycoplasma which Induces Acidity and Gytopathic Effect in Tissue Culture
}

\author{
By M. BUTLER AND R. H. LEACH \\ Department of Virology, Wellcome Research Laboratories, \\ Beckenham, Kent
}

(Received 29 July 1963)

SUMMARY

An agent which induced acidity and cytopathic effects in HEp-2 tissue cultures was investigated. The agent grew well in certain other tissue culture systems. Typical mycoplasma colonies were isolated from the contaminated HEp-2 cultures and on re-inoculation into HEp-2 cultures produced effects indistinguishable from the original effects. There was no appreciable growth in tissue culture medium alone. The mycoplasma had biological properties similar to those of known mycoplasmas, including Mycoplasma hominis type 1 (the common tissue culture contaminant), but was serologically distinct from these. Fluorescent antibody and Giemsastaining techniques showed extracellular forms. Other mycoplasmas were shown to grow in tissue culture; $\boldsymbol{M}$. gallisepticum induced similar effects to the cytopathic agent but was distinct in serological and biological properties. The agent partially inhibited the growth of measles virus.

\section{INTRODUCTION}

Mycoplasmas are well-known contaminants of tissue culture. With few exceptions these contaminants have been identified as Mycoplasma hominis type 1. Kraemer, Defendi, Hayflick \& Manson (1963) reported unclassified mycoplasmas which had lytic activity for murine lymphoma cells. Apart from this example, striking cytopathic effects have not been reported in mycoplasma-contaminated tissue cultures (Rothblat, 1960; Carski \& Shepard, 1961), although certain experimentally infected tissue cultures showed some degeneration (Shepard, 1958; Nelson, 1960; CastrejonDiez, Fisher \& Fisher, 1963). We observed pronounced acidity and cytopathic effect in HEp-2 tissue cultures and this paper reports some of our observations and attempts to characterize the agent responsible for these effects.

\section{METHODS}

Organisms. Mycoplasma hominis type I, M. hominis type II, M. salivarium, $M$. bovigenitalium, M. gallisepticum, $M$. laidlawii, and $M$. iners were obtained from the stock culture collection held in these laboratories.

Tissue cultures. Monolayer primary tissue cultures of rabbit and monkey kidney (Erythrocebus patas, Macaca mulatta and M. irus) and HEp-2 and HeLa cells were prepared and maintained in the media described below. Cultures for experiments were grown in $6 \times \frac{5}{8}$ in. test tubes, each seeded with 200,000 cells in 2 ml. medium. The growth medium for HEp-2, HeLa and rabbit cultures was replaced by $1.5 \mathrm{ml}$. 
of maintenance medium 3-4 days after initiation and for monkey cultures at 6-8 days.

Media. Mycoplasmas were cultivated in Edward medium, similar to that described by Butler \& Knight (1960b) but with certain modifications. The horse serum component was not inactivated. Autolysed yeast extract was replaced by a $10 \%(\mathrm{v} / \mathrm{v})$ solution of a boiled aqueous extract of bakers' yeast (Chanock, Hayflick \& Barile, 1962). For semi-solid Edward medium $10 \%(v / v)$ of solid medium was mixed with liquid medium. For growth of HEp-2 and HeLa cultures, Eagle's medium (1959), containing $10 \%(\mathrm{v} / \mathrm{v})$ calf serum, $0.1 \%(\mathrm{w} / \mathrm{v})$ glucose, $0 \cdot 22 \%(\mathrm{w} / \mathrm{v})$ sodium bicarbonate, penicillin 200 units $/ \mathrm{ml}$., streptomycin 100 units $/ \mathrm{ml}$. was used; the maintenance medium differed only in that the concentration of serum was decreased to $1 \%(\mathrm{v} / \mathrm{v})$. The growth medium for monkey kidney cultures was Earle's balanced salt solution with $2.5 \%(\mathrm{v} / \mathrm{v})$ calf serum, $0.11 \%(\mathrm{w} / \mathrm{v})$ sodium bicarbonate, $0.5 \%(\mathrm{w} / \mathrm{v})$ lactalbumin hydrolysate and antibiotics as above. The maintenance medium consisted of Earle's balanced salt solution containing $0.5 \%(\mathrm{w} / \mathrm{v})$ lactalbumin hydrolysate, $10 \%(\mathrm{v} / \mathrm{v})$ liver digest (Smith, 1961), 0.14\% (w/v) bovine albumin, 0.22\% (w/v) sodium bicarbonate and antibiotics as above. For growth of young rabbit kidney cultures the medium differed from the monkey kidney medium in that the serum was present at a concentration of $5 \%(\mathrm{v} / \mathrm{v})$. The maintenance medium was based on that of Carski (1960), and consisted of Eagle's medium (1959) containing $0.5 \%$ $(\mathrm{w} / \mathrm{v})$ lactalbumin hydrolysate, $1 \%(\mathrm{v} / \mathrm{v}) \mathrm{M}$ arginine, $1 \%(\mathrm{v} / \mathrm{v}) \mathbf{0} \cdot 1 \mathrm{M}$ glycine, $\mathbf{0 . 2 2} \%(\mathrm{w} / \mathrm{v})$ sodium bicarbonate and antibiotics as above.

Viable counts. The number of viable mycoplasma particles present in Edward medium was counted by the method of Butler \& Knight $(1960 a)$. Titrations of tissue culture infective units were done by preparing serial decimal dilutions in Eagle's medium (1959) containing $0 \cdot 22 \%(w / v)$ sodium bicarbonate, and inoculating groups of 3-5 tubes with $0.5 \mathrm{ml}$. of each dilution. The titre was calculated using the Kärber equation and expressed as $\log _{10}$ TCID 50/0.5 ml. The end-point in the HEp-2 cultures was determined by cytopathic effect and acidity. In other tissue cultures the end-point was determined primarily by cytopathic effect but was always confirmed by subculture of fluid from the test cultures into HEp-2 tissue in which characteristic cytopathic effects developed.

Serology. Mycoplasma antigens were grown in fluid Edward medium, harvested by centrifugation and resuspended appropriately. For agglutination saline suspensions at an opacity equivalent to Brown's tube No. 2 were used. For complement fixation the suspending fluid was veronal buffered saline and the opacity was equivalent to Brown's tube No. 5. For rabbit immunization phosphate-buffered saline suspensions (opacity equivalent to Brown's tube No. 2) were inoculated intravenously on alternate days in doses of $0.2,0.4,0.8$ and $1.5 \mathrm{ml}$. Antigen for this purpose was grown in media containing rabbit serum instead of horse.

Growth inhibition and tube agglutination techniques were those of Edward \& Fitzgerald (1951, 1954). Complement fixation tests were based on Le Bouvier's (1952) modification of the plate technique of Fulton \& Dumbell (1949). Indirect fluorescent antibody tests were made with acetone-fixed colony impression films or infected tissue culture coverslip preparations. These were treated for $30-45 \mathrm{~min}$. at $37^{\circ}$ with hyperimmune rabbit serum followed by sheep anti-rabbit globulin coupled to fluorescein isothiocyanate (Burroughs Wellcome and Co.) for the fluorescing 
component. Each stage was followed by washing in phosphate-buffered saline $(\mathrm{pH} 7 \cdot 4)$ and the preparations were mounted in $10 \%$ glycerol, phosphate-buffered at $\mathrm{pH} \mathbf{7 \cdot 4}$.

\section{RESULTS}

\section{Recognition of the acid-inducing agent}

Acidity and cytopathic effect were first observed in monolayer cultures prepared from a line of HEp-2 cells which had been grown in a chemostat for several months. This culture subsequently died quite suddenly. The monolayer cultures developed an unusual degree of acidity about 7-9 days after growth initiation (a change to maintenance medium having been made 3-4 days after initiation). The acidity was coincident with rounding of the cells, which shrank and became granular, leaving many spindle-shaped cells and cells with long fibroblastic extensions. The granular rounded cells tended to form clumps and clusters which were easily shaken off the glass surface; finally all the cells became rounded and granular and fell off the glass. Plate 1 , fig. $1 a$, illustrates cell degeneration about 4 days after acidity was observed. Degeneration of the cell sheet was usually complete between 7 and 10 days after acidity appeared. Similar cultures showed no appreciable acidity or cytopathic effect when the medium was replaced at regular 3- to 4-day intervals. Also, cultures renewed at weekly intervals by treatment of the cell sheet with ethylenediaminetetra-acetate (EDTA) and seeding the cell suspension in growth medium into fresh bottles, remained apparently healthy; the medium in these cultures was replaced by maintenance medium 3-4 days after growth initiation.

\section{Growth of the agent in different tissue cultures}

The agent grew well in HeLa cell cultures in which it caused acidity and cytopathic effect very similar to that observed in HEp-2 cultures. In primary monkey kidney tissue there was only slight cytopathic effect and no acid formation. In Erythrocebus patas cultures there appeared at the edges of the culture swollen, granular, elongated and bizarre-shaped cells. This degeneration slowly spread to affect much of the cell sheet by about the second week after infection. The culture then showed signs of ageing and it became difficult to distinguish specific effects. In Macaca mulatta and $\boldsymbol{M}$. irus kidney cell cultures little evidence of degeneration was seen apart from fine granulation and a tendency for the cells to elongate. Rabbit kidney cell cultures were severely affected by a granular round cell degeneration, associated with the formation of clumps of fibroblasts and swollen cells. The cell sheet was eventually destroyed altogether. Titration of the agent in these cultures showed that they were equally sensitive to the agent (Table 1). The extent of growth of the agent in these cultures was not measured. The addition, to the maintenance medium on monkey kidney tissue cultures, of calf serum or glucose at the concentration used in HEp-2 media (viz. $1 \%$ ) did not affect the quality of cytopathic effect or cause the development of acidity.

Other properties of the agent

Effect of freezing. The agent survived at $-20^{\circ}$ to $-30^{\circ}$ in infected fluids and on agar for several months, but with some loss of viability. Infected fluid $\left(1 \mathrm{ml}_{2}\right.$ sample) also survived three successive cycles of rapid freezing in ethanol + solid CO. 
mixture followed by quick thawing in water at $25^{\circ}$ with a loss of only one-tenth of the viability.

Effect of diethyl ether. One ml. infected fluid was mixed with $1 \mathrm{ml}$. ether and incubated for $1 \mathrm{hr}$ at $37^{\circ}$, after which the ether was removed by bubbling air through the mixture. The agent was not detected in HEp-2 cultures inoculated with the ether-treated samples. Fluid from these cultures was removed after 15 days and subcultured in fresh HEp-2 cultures which also remained healthy.

Table 1. Titration of the acid-inducing agent in various tissue cultures

$\begin{array}{ccc}\begin{array}{c}\text { Expt. } \\ \text { no. }\end{array} & \begin{array}{c}\text { Tissue } \\ \text { culture }\end{array} & \begin{array}{c}\text { Titre at 7 days* } \\ \left(\log _{10} \text { TCID 50/0.5 ml. }\right)\end{array} \\ 1 & \text { HEp-2 } & 10^{7 \cdot 15} \\ 2 & \text { HEp-2 } & 10^{6.5} \\ 3 & \text { HEp-2 } & 10^{6.75} \\ 4 & \text { HEp-2 } & 10^{8 \cdot 5} \\ & \text { Patas } & 10^{6.5} \\ 5 & \text { HEp-2 } & 10^{6.25} \\ & \text { Rhesus } & 10^{6 \cdot 5} \\ 6 & \text { HEp-2 } & 10^{5 \cdot 5} \\ & \text { HeLa } & 10^{5 \cdot 5} \\ & \text { Patas } & 10^{5 \cdot 5} \\ & \text { Rabbit } & 10^{5.5}\end{array}$

* Titre determined by presence of cytopathic effects.

Effect of tetracycline hydrochloride. The agent did not grow in HEp-2 cultures bathed in maintenance medium containing tetracycline $2.5 \mu \mathrm{g}$. $/ \mathrm{ml}$. Samples from inoculated cultures were removed after 15 days and subcultured in fresh HEp-2 cultures which remained healthy. The agent had been isolated from cultures containing penicillin and streptomycin. All the work was carried out in the presence of these two antibiotics and no attempt was made to find out whether the antibiotics were inhibitory at higher concentrations; but the agent grew equally well in their absence.

Pathogenicity for mice. New-born mice inoculated intracerebrally (0.01 ml.) and intraperitoneally $(0 \cdot 1 \mathrm{ml}$.) remained healthy for 14 days. No cultures were made from these animals.

\section{Growth and biological properties of the cytopathic agent in cell-free media}

From HEp-2 cultures showing acid and cytopathic effects, mycoplasma-like colonies were grown on Edward solid medium directly or after initial passage in semi-solid medium. When aerobic conditions were used for primary culture relatively few colonies were obtained. However, incubation in $5 \% \mathrm{CO}_{2}$ in nitrogen usually resulted in profuse growth. Initially colonies were very granular with poorly defined centres, but after several subcultures they had the typical 'fried-egg' appearance of mycoplasmas. A single colony clone was obtained before further biological and antigenic properties of the agent were examined. Cultures of this organism inoculated into HEp-2 cultures produced characteristic acidity and cytopathic change 
indistinguishable from the original effects. From such infected cultures the mycoplasma was re-isolated. The agent inoculated into HEp-2 maintenance medium showed a tenfold increase in titre during the 1st day, followed by a decline to zero within 14 days. No acidity was produced nor was any turbidity detected.

By using some of the criteria listed by Edward (1954, Table 1) for distinguishing between mycoplasmas the following characters were noted for the agent grown in Edward medium. It grew well on medium containing rabbit serum instead of horse serum but did not grow in the absence of serum. 'Film and spots' were produced on horse serum agar medium. Glucose was not fermented. Only a faint trace of $\alpha$-type lysis was observed on horse blood agar medium. Colonial growth was unaffected by omission of penicillin and thallium acetate. In semi-solid medium growth was diffuse. In liquid medium a faint turbidity developed. On the basis of these properties alone the organism could not be distinguished from Mycoplasma hominis type $\mathbf{I}$, the commonest mycoplasma contaminant of tissue culture cell lines, or from M. hominis type II, M. salivarium (Edward, 1954; Freundt, 1958) and $M$. iners (Edward \& Kanarek, 1960).

\section{Serological characters of the agent}

Serological comparisons were made between the acid-forming mycoplasma and Mycoplasma hominis types I and II, M. salivarium and $M$. iners, which were very similar to the agent in biological tests. By complement fixation and agglutination tests the agent differed from the named mycoplasmas (Table 2). In growth inhibition

Table 2. Serological comparison of acid-inducing (4.I.) mycoplasma with named species having similar biological properties

Titres expressed as reciprocals of serum dilutions.

\begin{tabular}{|c|c|c|c|c|c|c|c|c|c|c|}
\hline Antiserum ... & $\begin{array}{r}\text { A } \\
\text { mycoI }\end{array}$ & plasma & M. & minis & $\begin{array}{l}M . h o \\
\text { type }\end{array}$ & $\begin{array}{l}\text { ninis } \\
\text { II }\end{array}$ & & sali- & $M$. & ers \\
\hline Antigen & C.F.* & Agg. $\dagger$ & C.F. & Agg. & C.F. & Agg. & C.F & Agg. & C.F. & Agg. \\
\hline A.r. mycoplasma & $160-640$ & $128-256$ & 10 & 4 & $<10$ & $<4$ & 10 & 8 & $<10$ & 8 \\
\hline $\begin{array}{l}\text { M. hominis } \\
\text { type I }\end{array}$ & $<\mathbf{2 0}$ & $<4$ & 80 & $128-256$ & - & - & 一 & - & - & - \\
\hline $\begin{array}{l}\text { M. hominis } \\
\text { type II }\end{array}$ & - & $<4$ & - & 一 & $80-160$ & 256 & 一 & 一 & - & 一 \\
\hline M. salivarium & 一 & - & - & - & 一 & - & 640 & 256 & 一 & - \\
\hline M. iners & - & - & - & 一 & - & 一 & - & - & 160 & 64 \\
\hline
\end{tabular}

tests (Edward \& Fitzgerald, 1954) there was partial inhibition of the agent by homologous antiserum but no inhibition by antisera to the other mycoplasmas. In HEp-2 cultures in the presence of $1 / 20$ antiserum acidity and cytopathic effects were delayed for several days and were not so pronounced as in normally infected cells. Results of the fluorescent antibody staining technique, described in the next section, confirmed the distinct serological character of the agent. 


\section{Staining the agent in tissue culture}

Normal HEp-2 cells were grown on glass coverslips and samples were taken at various stages after infection with a strain of the agent which had always been grown in HEp-2 culture. The preparations were fixed in acetone and stained by the intensified Giemsa stain of Marmion \& Goodburn (1961). When the cultures showed characteristic acid degeneration numerous faint-staining particles of less than $0.5 \mu$ appeared, lying mainly outside but also around and on the tissue cells (Pl. 1, fig. $1 b$ ). There were similar particles in deposits of HEp-2 cells from severely degenerated cultures. Their shape and size indicated that these particles were probably the mycoplasma that could be isolated from such cultures. This was confirmed when apparently identical particles were stained specifically by the indirect fluorescent antibody by using hyperimmune rabbit serum prepared against Edward medium cultures of the agent. Such particles did not stain when treated with antisera prepared against Mycoplasma hominis types I and II. No such particles were detected either by Giemsa or by fluorescent antibody stains in healthy HEp-2 cultures.

Table 3. Growth of various mycoplasma in $\mathrm{HEp}$-2 tissue culture

\begin{tabular}{|c|c|c|c|c|c|}
\hline \multirow[b]{3}{*}{ Organisms } & \multicolumn{3}{|c|}{ First culture } & \multicolumn{2}{|c|}{ Subculture of 14-day flui } \\
\hline & \multicolumn{2}{|c|}{ Colony count } & \multirow{2}{*}{$\begin{array}{c}\text { Condition } \\
\text { of culture. } \\
14 \text { days }\end{array}$} & \multirow{2}{*}{$\begin{array}{l}\text { Colony } \\
\text { count. } \\
11 \text { days }\end{array}$} & \multirow{2}{*}{$\begin{array}{c}\text { Condition } \\
\text { of culture. } \\
11 \text { days }\end{array}$} \\
\hline & Zero & 14 days & & & \\
\hline Acid-inducing agent & 3.48* & $5 \cdot 48$ & cpe $+\mathbf{a} \dagger$ & Not done & $\mathbf{c p e}+\mathbf{a}$ \\
\hline$M$. hominis type I & $\mathbf{3} \cdot \mathbf{1 1}$ & $3 \cdot 48$ & Healthy & $4 \cdot 48$ & Healthy \\
\hline M. hominis type II & $1 \cdot 48$ & 0 & Healthy & 0 & Healthy \\
\hline M. bovigenitalium & $\mathbf{3} \cdot 48$ & 0 & Healthy & $\mathbf{0}$ & Healthy \\
\hline M. gallisepticum & $3 \cdot 48$ & $\mathbf{3} \cdot 48$ & Healthy & $5 \cdot 48$ & cpe $+\mathbf{a}$ \\
\hline M. laidlazeii & 0 & $5 \cdot 48$ & Healthy & $5 \cdot 48$ & Healthy \\
\hline
\end{tabular}

Comparison of the growth of the agent and other mycoplasmas in HEp-2 cultures

Cultures of the cytopathic agent, Mycoplasma hominis types I and II, M. bovigenitalium, M. gallisepticum and $M$. laidlarvii, all grown in liquid Edward medium, deposited by centrifugation and resuspended in HEp-2 maintenance medium, were inoculated into cultures of HEp-2 cells. Samples from the inoculated cultures were removed, immediately and after 14 days of incubation, for colony counts. Subcultures $(0.2 \mathrm{ml}$.) from the 14-day fluids were made into fresh HEp-2 cultures and colony counts made 11 days later. All cultures were examined periodically for cytopathic effect or acidity; Table 3 summarizes the results. The agent produced typical acidity and cytopathic effect and colonies were isolated after 14 days' incubation. Mycoplasma hominis type I and $M$. laidlawii appeared to grow quite well but had no detectable effect on the HEp-2 cells; $M$. hominis type II neither survived nor altered the cell sheet; $M$. gallisepticum, however, produced both cytopathic effect and acidity in the subcultures in HEp-2 cells and evidently grew 
actively; $M$. gallisepticum differed from the acid-inducing mycoplasma in certain biological properties, e.g. production of large colonies and of acid from glucose, and was serologically distinct in slide-agglutination tests.

\section{Effect of the agent on virus growth}

Following preliminary observations that the growth of measles virus in HEp-2 cultures was affected by the agent, HEp-2 cultures infected with the agent were super-infected with measles virus 2 days later. After 9 days the measles virus grown in healthy HEp-2 tissue had a titre of $10^{5.5} \mathrm{TCID} \mathrm{50/0.5} \mathrm{ml.} \mathrm{(the} \mathrm{expected} \mathrm{value)} \mathrm{but}$ in the presence of the acid-inducing agent, when the cultures were only slightly acid, the titre was $10^{4.5}$. However, at 14, days such cultures were completely degenerated. Measles virus growth was not affected by the presence of the laboratory strain of Mycoplasma hominis type I.

\section{DISCUSSION}

There is no doubt that the agent responsible for the acid-inducing and cytopathic changes in tissue culture was a mycoplasma. Typical mycoplasmas were demonstrated by staining and by cultivation from tissues contaminated with the agent, but were not present in healthy cultures. The characteristic acid production and cytopathic changes were reproduced by cultures of the mycoplasma following several serial passages in artificial medium. The properties of the agent, including susceptibility to ether and tetracycline hydrochloride and insensitivity to penicillin, were those of the mycoplasma group. Furthermore, experimental infection with the agent was partially inhibited by rabbit antiserum prepared against pure cultures of the isolated mycoplasma. The organism retained the typical colonial and cultural characteristics of a mycoplasma after several cycles of growth in tissue cultures without antibiotics.

As with most other reported instances of mycoplasma infection of tissue cultures the source of the contamination is unknown. Some workers (Rothblat \& Morton, 1959) have suggested that such contaminants may be L-phases of bacteria. Barile, Malizia \& Riggs (1962) reported a much lower frequency of contaminants in tissue cultures from laboratories where cells were maintained mainly in the absence of antibiotics. They interpreted this as supporting the hypothesis of the bacterial origin of the contamination. The strains they isolated were antigenically identical but unrelated to certain named species of mycoplasma, including Mycoplasma hominis type II. However, later findings (Dr M. F. Barile, personal communication) have shown that they were in fact $M$. hominis type I. It is more likely that the low frequency of mycoplasma contamination in tissue cultures without antibiotics reflects the use of a necessarily more careful aseptic technique. Although no objective criteria have been established for distinguishing absolutely between mycoplasmas and L-phase organisms, Dienes, Edward, Freundt \& KlienebergerNobel (Discussion, 1960), have pointed out that there exist profound differences between the two groups of organisms. We are satisfied on their criteria that the colonial and cultural appearance of our agent are those of a mycoplasma.

In view of the striking cytopathic effects produced by our agent it is interesting that, on the basis of biological and antigenic properties, it is unrelated to any of the established Mycoplasma species including Mycoplasma hominis type I. To our 
knowledge, apart from isolated instances involving $M$. hominis type II (Bailey et al. 1961) or $M$. gallisepticum (Edward, 1960) almost all fully investigated cases of mycoplasma contamination of cell lines were due to $M$. hominis type I (Collier, 1957; Coriell, Fabrizio \& Wilson, 1960; Bailey et al. 1961) and did not involve the pronounced acid and cytopathic changes characteristic of the acid-inducing mycoplasma. Usually mycoplasma contaminations are only revealed by specific cytological or cultural investigations (Hayflick \& Stinebring, 1960; Rothblat, 1960) and in this connexion it is noteworthy that $M$. hominis produced no detectable changes when growing in our HEp-2 cultures. Of two other mycoplasmas which grew very freely in HEp-2 cultures, $M$. laidlarwii produced no obvious changes but $\boldsymbol{M}$. gallisepticum caused acidity and cytopathic effect. Castrejon-Diez et al. (1963) observed similar effects with $M$. gallisepticum and suggested that the acidity was due to the production of acetate. It is improbable that the acid changes in HEp-2 and HeLa cultures caused by our agent were due simply to the effect of the agent on the sugarcontaining cell culture medium, since the acid-inducing mycoplasma itself cannot ferment glucose in cell-free medium or produce acid in tissue culture media. As the agent caused observable cytopathic effects in both monkey and rabbit kidney tissue cultures without any acidification, the changes in HEp-2 cultures were probably due to its action on cell metabolism. Mycoplasmas are known to be able to influence the metabolism of animal cells in tissue culture (Powelson, 1961; Kenny \& Pollock, 1963; Schimke \& Barile, 1963).

Rouse, Bonifas \& Schlesinger (1963) observed inhibition of adenovirus by mycoplasma. The ability of our agent to inhibit the growth of measles virus is another illustration of the hazards of mycoplasma contamination of tissue culture. Coriell, Tall \& Gaskill (1958) pointed out that the use of such cultures for the production of virus antigen could also complicate the results of virus antibody-antigen studies. These observations of ours and others stress the importance of frequent testing of tissue cultures for the presence of mycoplasma. Without such checks, the present agent might easily have been assumed from its cytopathic effects to be a virus contaminant.

We are indebted to Dr D. G. ff. Edward for valuable critical discussions and to several people, including particularly Mrs M. Brereton, for their technical assistance.

\section{REFERENCES}

Bailey, J. S., Clark, H. W., Felts, W. R., Fowler, R. C. \& Brown, T. McP. (1961). Antigenic properties of pleuropneumonia-like organisms from tissue cell cultures and the human genital area. J. Bact. 82, 542.

Barile, M. F., Malizia, W. F. \& Riggs, D. B. (1962). Incidence and detection of pleuropneumonia-like organisms in cell cultures by fluorescent antibody and cultural procedures. J. Bact. 84, 130.

Butler, M. \& KNIGHT, B. C. J. G. (1960a). The survival of washed suspensions of Mycoplasma. J. gen. Microbiol. 22, 470.

Butler, M. \& KNIGHT, B. C. J. G. $(1960 b)$. The measurement of the growth of Mycoplasma in liquid media. J. gen. Microbiol. 22, 478.

Carski, T. R. (1960). A fluorescent antibody study of the simian foamy agent. J. Immunol. 84, 426.

Carski, T. R. \& Shepard, C. C. (1961). Pleuropneumonia-like (Mycoplasma) infections of tissue culture. J. Bact. 81, 626. 
Castrejon-Diez, J., Fisher, T. N. \& Fisher, E. (1963). Experimental infection of tissue cultures with certain mycoplasma. Proc. Soc. exp. Biol., N.Y. 112, 643.

Chanock, R. M., Hayflick, L. \& Barile, M. F. (1962). Growth on artificial medium of an agent associated with atypical pneumonia and its identification as a PPLO. Proc. nat. Acad. Sci., Wash. 48, 41.

Collier, L. H. (1957). Contamination of stock lines of human carcinoma cells by pleuropneumonia-like organisms. Nature, Lond. 180, 757.

Coriell, L. L., Fabrizio, D. P. \& Wilson, R. S. (1960). Comparison of PPLO strains from tissue culture by complement fixation. Ann. N.Y. Acad. Sci. 79, 574.

Coriell, L. L., Tall, M. G. \& Gaskill, H. (1958). Common antigens in tissue culture cell lines. Science, 128, 198.

Discussion (1960). Part III. Biology of the pleuropneumonia-like organisms. Ann. N.Y. Acad. Sci. 79, 481.

EAGLe, H. (1959). Amino acid metabolism in mammalian cell cultures. Science, 130, 432.

EDWARD, D. G. FF. (1954). The pleuropneumonia group of organisms: a review, together with some new observations. J. gen. Microbiol. 10, 27.

EDWARD, D. G. FF. (1960). Biology of the pleuropneumonia-like organisms. Discussion of Part II. Ann. N.Y. Acad. Sci. 79, 459.

Edward, D. G. FF. \& FitzGerald, W. A. (1951). The isolation of organisms of the pleuropneumonia group from dogs. J. gen. Microbiol. 5, 566.

Edward, D. G. FF. \& Fitzgeratd, W. A. (1954). Inhibition of growth of pleuropneumonia-like organisms by antibody. J. Path. Bact. 68, 23.

EDWARD, D. G. FF. \& KanAREK, A. D. (1960). Organisms of the pleuropneumonia group of avian origin: their classification into species. Ann. N.Y. Acad. Sci. 79, 696.

Freundt, E. A. (1958). The Mycoplasmataceae. Copenhagen: Munksgaard.

Fulton, F. \& Dumbell, K. R. (1949). The serological comparisons of strains of influenza virus. J. gen. Microbiol. 3, 97.

HAYFLick, L. \& Stinebring, W. R. (1960). Intracellular growth of pleuropneumonialike organisms (PPLO) in tissue culture and in ovo. Ann. N.Y. Acad. Sci. 79, 433.

KenNy, G. E. \& Pollock, M. E. (1963). Mammalian cell cultures contaminated with pleuropneumonia-like organisms. I. Effect of pleuropneumonia-like organisms on growth of established cell strains. J. infect. Dis. 112, 7.

Kraemer, P. M., Defendi, V., Hayflick, L. \& Manson, L. A. (1963). Mycoplasma (PPLO) strains with lytic activity for murine lymphoma cells in vitro. Proc. Soc. exp. Biol., N.Y. 112, 381.

LE Bouvier, G. L. (1952). Observations on the poliomyelitis complement fixation test. Br. J. exp. Path. 34, 300.

Marmion, B. P. \& Goodburn, G. M. (1961). Effect of an organic gold salt on Eaton's primary atypical pneumonia agent and other observations. Nature, Lond. 189, 247.

Nelson, J. B. (1960). The behaviour of murine PPLO in HeLa cell cultures. Ann. N.Y. Acad. Sci. 79, 450.

Powelson, D. M. (1961). Metabolism of animal cells infected with mycoplasma. J. Bact. 82, 288.

Rothblat, G. H. (1960). PPLO contamination in tissue cultures. Ann. N.Y. Acad. Sci. 9, 430.

Rothblat, G. H. \& Morton, H. E. (1959). Detection and possible source of contaminating pleuropneumonia-like organisms (PPLO) in cultures of tissue cells. Proc. Soc. exp. Biol., N.Y. 100, 87.

Rouse, H. C., Bonifas, V. H. \& Schlesinger, R. W. (1963). Dependence of adenovirus replication on arginine and inhibition of plaque formation by pleuropneumonia-like organisms. Virology, 20, 357.

Schimke, R. T. \& Barile, M. F. (1963). Arginine breakdown in mammalian cell culture contaminated with pleuropneumonia like organisms (PPLO). Expl. Cell Res. 30, 593.

Shepard, M. C. (1958). Growth and development of T strain pleuropneumonia-like organisms in human epidermoid carcinoma cells (HeLa). J. Bact. 75, 351.

Smrth, S. E. (1961). A maintenance medium for tissue culture virus studies. Br. J. exp. Path. 42, 232. 


\section{EXPLANATION OF PLATE}

The effect of the acid-inducing agent on a HEp-2 monolayer.

Intensified Giemsa stain.

Fig. 1. About 4 days after acidity observed $(a) \times 200,(b) \times 1250$.

Fig. 2. Uninoculated culture of the same age $(a) \times 200,(b) \times 1250$. 

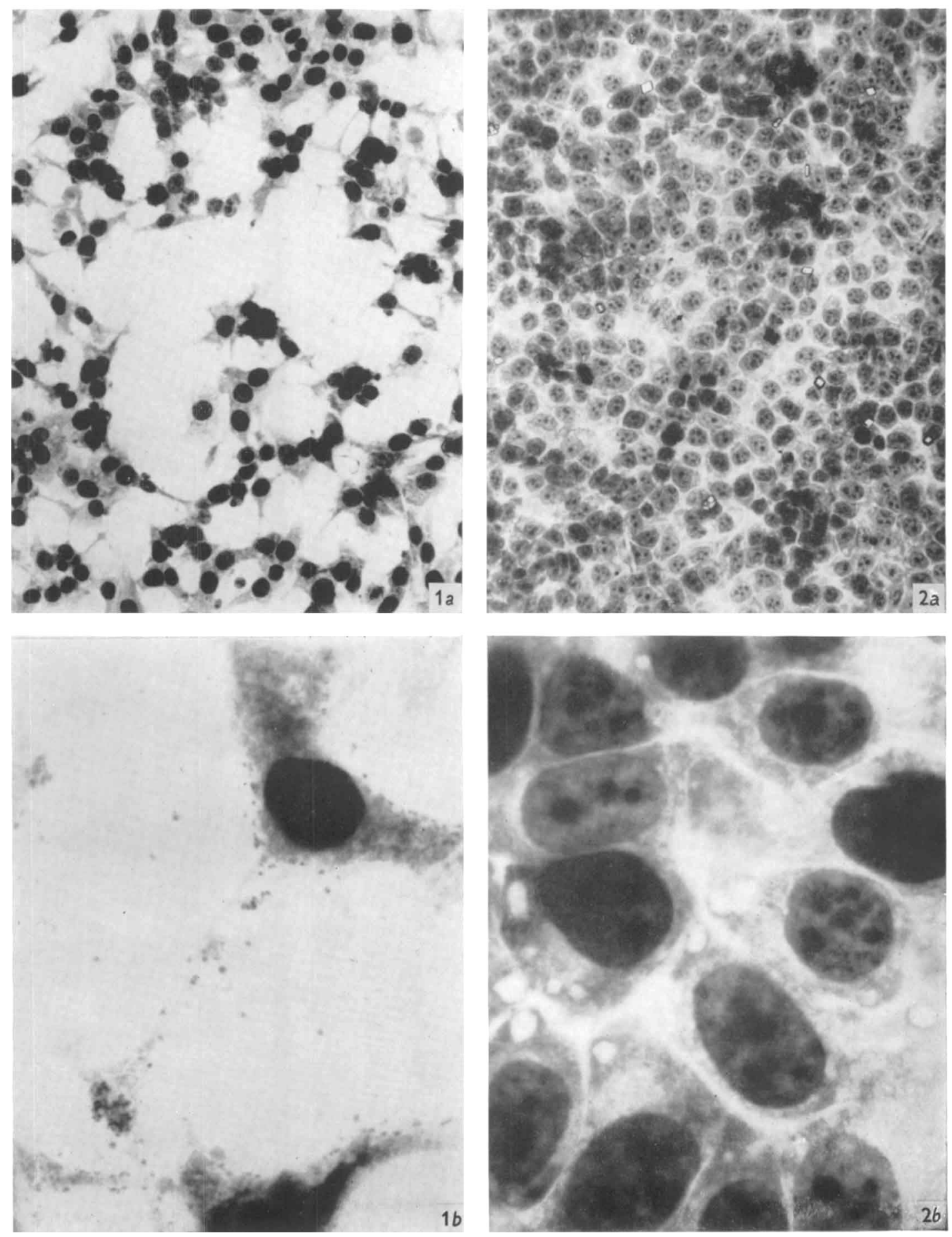

M. BUTLER AND R. H. LEACH

(Facing p. 294) 